\title{
International Human Rights Law and The Progressive Muslim's Perspective on Lesbian, Gay, Bisexual and Transgender Status in Indonesia
}

\author{
Asmawi \\ Syarif Hidayatullah \\ State Islamic University of Jakarta, \\ Indonesia \\ asmawi@uinjkt.ac.id
}

\author{
Yuli Yasin \\ Syarif Hidayatullah \\ State Islamic University of Jakarta, \\ Indonesia
}

\begin{abstract}
This study focuses on the problem of how the views of the Progressive Muslim scholars on the status of LGBT in Indonesia and how the views of the Progressive Muslim scholars are influenced by international human rights law. The findings of this study indicated that the Progressive Muslim scholars do reinterpretation on the Quranic verses and Hadith texts of LGBT status in order to ensure the compatibility of Islam with the humanism values so that Islam comes forth as a positively "humanizing" religion. The Progressive Muslim scholars' reinterpretation of the sacred Islamic texts on the LGBT status is greatly influenced by the values and norms of international human rights so that their views undergo interpolation with international human rights law. The study concluded that LGBT behaviors are more a deviation, not nature, so it is still possibly cured and rehabilitated. The Progressive Muslim scholars' arguments, that consider LGBT behaviors as nature, are hence disputable. LGBT behaviors are more a nurture that can be formed and also be eliminated. This is the most steady denial on the Progressive Muslim scholars' arguments. Consequently, the Progressive Muslim's views on LGBT status are so weak in its argument that untenable.
\end{abstract}

Keywords-LGBT; Human rights; Progressive Muslim;

\section{INTRODUCTION}

Tom Boellstorff $(2005: 234)$ noted that LGBT groups dubbed "gay" and "lesbian" foreigners into Indonesian gays and lesbians, through a series of identification, sexual practices, and social contexts that presented original Indonesian taste (Boellstorff, 2005:234).According to Diego García Rodríguez (2015:53), in Indonesia Progressive Muslim scholars, it became the main mouthpiece in presenting the academic discourse with LGBT pro-activism. Diego García Rodríguez's study finds that LGBT Muslim groups are willing to oppose and dispute Traditional Islam scholars that view LGBT as a sin; however, they are not strong enough to do it alone; and on this case, they heavily rely on Progressive Muslim scholars (2015:54).

The Progressive Muslim scholars' perspective on the status of LGBT brings in a controversy. This is because the Progressive Muslim scholars, in addition to applying human rights issues in context of protecting and promoting LGBT's interests as conducted by Zainul Hamdi (in Rodríguez,
2015:33), also reinterpreted the authoritative Islamic sacred texts (Qur'an and Sunnah) within the framework of international human rights standards and principles as undertaken by Musdah Mulia (2009). Of course, this perspective needs to be examined academically to ensure its validity, which in turn determines the validity of the Progressive Muslim scholars' views on the status of LGBT in Indonesia.

This paper focused on how the Progressive Muslim scholars' views on LGBT status and what is the effect of international human rights law to the Progressive Muslim scholars' views.

This study applied qualitative data collected through documentary study and interview. The interviewees are Mr. Agung Sugiharto (Sinyo) and Mrs. Shinta Ratri, the first one is Director of Peduli Sahabat Foundation at Magelang and the last one is Head of Al-Fatah Gay Islamic Boarding School at Yogyakarta. In addition, we also conducted library research.

\section{Human Rights AND SEXUAlity: THEORETICAL PERSPECTIVE}

Lucie Cviklová (2012:59) underlined that Muslim countries seem so far from the ability to adopt international human rights standards and principles to ensure LGBT people savoring basic rights, as well as those heterosexuals, enjoy. Ersilia Francesca (in Ahmadi, 2012) emphasized that the Progressive Muslim scholars have agreed with Christian and Jewish scholars in making Islamic sacred texts a proof of causality of homosexuality and the spread of AIDS in the contemporary society because-according to them-AIDS is a punishment for modern-day homosexual behavior. Scott Siraj al Haqq Kugle (in Safi: 2003: 204) confirmed that the divine punishment of the Luth's people is not on homosexual behavior but on the offense and the rape of the guests they committed. Diego García Rodríguez (2015:55) explained that Progressive Muslim scholars have offered a new perspective in understanding authoritative Islamic sacred texts that lead to acceptance of the status of Islamic minority groups; and more than that, the LGBT people have found a new promoting view 
on their status through the reinterpretation of the Progressive Muslim scholars.

Meanwhile, Jurgen Gerhards (2010:15) notes that adherence of a religion will affect the adherent to behave nondiscriminative on LGBT status and many religions indicate different interpretation and attitudes on LGBT status. Therefore, Jurgen Gerhards (2015) underlined that the interpretation of a religion will affect the attitudes of its adherents. The more LGBT is rejected and interpreted as a deviant behavior by a religion, the more adherents of such religion will reject the LGBT people.

However, Walter L. Williams (2009:17) stated that there are a number of Muslim countries that are no longer active in criminalizing homosexual people, and they can be the model of change conducting by the homophobic government. While E. Blackwood (2007:294) declared that Indonesia maintains its neutral attitude on homosexuality. As evidence, since the independence of 1945, no law that have qualified LGBT behavior as unlawful. In Indonesia, the national law system-in a broad sense does not support LGBT people even though homosexuality itself is not stipulated as a crime. A number of local regulations prohibit homosexuality and consider it as a crime because it is seen as an immoral act.

In his study Moh. Nur Ichwan (2013:11) argued that LGBT people need Muslim intellectuals who so voiced and promoted LGBT people's status; and of course, the Progressive Muslim scholars contribute significantly to construct the concept of LGBT people's status. Javaid Rehman and Eleni Polymenopoulou (Rehman, 2013:50) confirmed that strategy of LGBT people's empowerment can be undertaken by reinterpretation of Islamic teachings based on international human rights law standards and principles.

The international human rights law refers to what is known as the international bills of rights, namely, firstly the Universal Declaration of Human Rights (UDHR); secondly, International Covenant on Civil and Political Rights (ICCPR) of 1966; and then thirdly, International Covenant on Economic, Social and Cultural Rights (ICESCR) of 1966. Indonesia has ratified the ICCPR by Law of 12 of 2005 on the Ratification of the International Covenant on Civil and Political Rights, in addition to ratifying the International Covenant on Economic, Social and Cultural Rights (ICESCR) by Law of 11 of 2005 on Ratification of International Covenant on Economic, Social and Cultural Rights. Many scholars promoting LGBT people's status make international human rights standards and principles as the primary medium for defending and promoting their own status.

\section{REINTERPRETAtion OF PROgRessive MusLim On LGBT STATUS}

The term of Progressive Muslim is a new term in contemporary Islamic studies used by academicians and activists since the last few years to label the understanding and actions of Muslims who strive for the upholding of humanist values, such as the development of civil society, democracy, justice, gender equality, defence of the oppressed, and pluralism. Progressive Muslim has a vision of presenting Islam in an elegant, well-adjusted and well-dialogue able way with modernity, but at the same time maintaining its traditions, conserving its authenticity and preserving its identity (Safi, 2003:3).

As a Progressive Muslim scholar, Musdah Mulia (2015:24) insisted that the social construction of society for centuries forced the hetero-normativity or norms of heterosexual orientation as the only truth, it is no wonder that homosexual orientation and other sexual orientations were considered distorted, abnormal and unnatural. According to Musdah Mulia (2015:25), the interpretation of any religion, including the Islamic interpretation, is hegemonized by heteronormativity, the ideology that requires humans to pair up the opposite sex and must obey the rules of heterosexuality that sets out the aim of marriage is solely for procreation or production of offspring. Heteronormativity sees that normal, good, natural, and ideal sexuality is heterosexual, marital, reproductive, and non-commercial one. In contrast, homosexuals, gays or lesbians, and prostitution are considered immoral, unreligious, forbidden, social disruption.

In the Qur'an, according to Mohd Izwan bin Md Yusof's study (23), none of the verses explicitly reject LGBT. He considers that anti-LGBT viewpoint is all based on the verses telling the story of Prophet Luth, as it is contained in Q.S. alA'râf $/ 7: 80-81$. The message to be addressed in this story is not as a prohibition on LGBT, but as a "comforter story" to strengthen the Prophet's mentality in the preaching of Islam that is rejected by the Quraysh community. The LGBT in the Qur'an gets its place if it realizes that the diversity of sexual orientation as a part of something innate (natural, character). This is stated in Q.S. al-Isrâ '/17:84. In addition, it is crucial to distinguish between the verses of the law and the verses of the story, which certainly cannot be directly linked with the rules of law. In this context, the story of Luth that seems similar to the story of Sodom and Gomorrah. Not all verses of the story can be the basis of the moral law because they may be metaphors.

According to Progressive Muslim scholars, there is no corporal punishment for homosexual, while any Hadith, that has been referred to condemn homosexuals and impose corporal punishment on the homosexual, is considered invalid (da' $\hat{\imath} f)$. This opinion can certainly be argued that the Hadith of that corporal punishment is narrated by many reporters of Hadith such as Mâlik ibn Anas, Abû Dâwud, al-Turmudzî, Ibn Mâjah, Ibn Hibbân, al-Tabrânî, al-Hâkim, and al-Baihaqî.

In discussing the issue of sexuality, we are faced with 2 (two) major theories. First, the theory of essentialism which argues that the origin of the sex problem lies on the chromosome. This theory declares that sexual behavior, in the approach of essentialism theory, is driven by a libido which is also given and already exists in the human body. Second, the theory of social construction which assumes that human sexual activity, in contrast to animals, is the result of social construction (thoughts, worldviews and relational behaviour) of human beings and establishes the concept of "sexuality", the activity that departs from the way of thinking, values, 
worldviews and how human being, men, and women, are expected to behave sexually.

Thus, it can be asserted that the Progressive Muslim scholars have reinterpreted the verses of the Qur'an and the Hadith text on LGBT status. This is done in order to ensure the compatibility of Islam with the values of humanism so that Islam arises as a religion that really "humanize human being". Therefore, for the Progressive Muslim scholars, LGBT is the human being of God's creation who must be glorified like the others.

\section{INTERNATIONAL HUMAN RIGHTS LAW AND REINTERPRETATION OF PROGRESSIVE MUSLIM}

The Progressive Muslim scholars consider human rights principles demand a parameter restricting the essential freedom that should be the subject to testing the level of need and proportionality. Restriction of the freedom, especially in the case of private affairs and important affairs such as sexuality, should be strictly scrutinized. Proponents of such restrictions should be required to demonstrate that criminalization achieves the claimed goal of protecting the family in a particular model and that it must exist and be proportionate to that goal. The criminalization actually has failed in the test at the UN Human Rights Committee.

Sonia Corrêa (2008:19) argues that human rights history undergoes a series of momentum in which religious dogmatism urges social conflict and contaminates state rationality, but religious extremism can no longer be described as a phenomenon bounded by national, institutional and societal boundaries. In its historical dynamics, there is a moment in which human rights come into contact with the issue of sexuality. Susan F. Tried (273) stressed that the effort to develop the conceptualization of sexuality and human rights has been going on since two decades ago. A number of movements actively initiate and participate in a process of achieving a better understanding of sexuality in the context of human rights.

The Islamic orthodoxy scholars who justify their judgment of gays often refer to the verses of the Qur'an and Hadith to support their attitudes. When Islam, according to its basic meaning, promotes peace in all dimensions of life, many Muslim homosexuals are struggled to make peace with an Islamic reality that does not accept them. This often instills a sense of alienation from their community and the feeling of being rejected by God, friends, and family. For many homosexuals, instant sex, alcohol, addictive substance abuse, suicide attempts, and apostasy are the way out for negotiating the dilemma between Islam and sexuality (Hendricks, 2010:32).

Everyone has the right to enjoy human rights without discrimination based on sexual orientation and gender identity. Everyone is entitled to equality before the law and protection of the law without any discrimination that does not affect the enjoyment of human rights. The law also prohibits such discrimination and ensures equal and effective protection to discrimination against everyone. Discrimination on the basis of sexual orientation and gender identity can be and is often caused by discrimination on other grounds that include race, age, religion, disability, health and economic status. States shall promote the principles of equality and nondiscrimination on the basis of sexual orientation and gender identity in the national constitution or other legislation if not already covered, including a way of altering and interpreting them and ensuring the effective realization of those principles.

It is clear that the Progressive Muslim scholars' reinterpretation of Islamic sacred texts of LGBT status is strongly influenced by international human rights values and standards. The arguments they propose in interpreting the Quranic verses and the anti-LGBT Hadith texts may be criticized by the optics of international human rights law, which appears to be more an interpolation. Sexual rights are one of the most important human rights and their fulfillment cannot be ignored at all. Everyone-without distinction in any case, including gender identity and sexual orientation is entitled to enjoy sexual rights without discrimination. States and societies are obliged to assist in the fulfillment of such sexual rights and to promote the principles of nondiscrimination, non-violent, and equality for all persons.

In international human rights instruments, it is stated that the fulfillment of human sexual rights is based on seven main principles, namely sexual rights as a human rights, protection for the growth of children, non-discrimination, pleasure and comfort, responsible freedom, respect to human freedom, and fulfillment of rights.

Sexual orientation is the capacity of everyone related to emotional attraction, affection, and sexual intercourse. Sexual orientation is natural and irreversible. No one can choose to be born with a particular sexual orientation. Sexual orientation is the nature or gift of God. In other words, a sexual orientation (homosexual and heterosexual) is not an artificial nature or behavior but is created by God.

Since the Qur'an does not specifically address homosexuality, where there is ambiguity between Shari'a and the interpretation of the Qur'an and Hadith, and Shari'a adopted the values and standards of a society, the Muslim people of the world must be glad to convey the status of homosexuality in Islam. So, they need to be involved in efforts to understand and accept LGBT Muslims.

In the classical sources of Islam, it is found that Islamic scholars classify the existence of "al-mukhannats" into two kinds, namely, "mukhannats khalqiy" (natural homosexual) and "mukhannats bi al-'amdi" (intended homosexual). Within classifying such two kinds, many classical Islamic scholars explain the law. They claim that "mukhannats khalqiy" (natural homosexual) should not be humiliated, stigmatized or punished. Abuses and punishments should only be imposed on "mukhannats bi al-'amdi" (intended homosexual).

There are several kinds of sexual orientation, i.e heterosexual, homosexual, bisexual and asexual. Heterosexual is when someone is interested in a different type of his/her self. Homo is if someone is interested in same-sex. Men attracted to each other are called gays; while women loving each other are called lesbians. Someone is called a whisper if his sexual orientation is multiple orientations: interested in the same sex as well as on the opposite sex. In contrast, asexuals 
are not interested in both, neither the same sex nor the opposite sex.

It is important to reconcile Islam and homosexuality by analyzing the experiences of LGBT Muslims through the convergence of religious leaders, their gender and the identification of their sexual orientation. Spiritual identity and gender or sexual identity is a fundamental element of individual identity and the deepest aspect of everyone's privacy. In examining the identity of LGBT Muslims, we must understand the power given to this community, and the pressure on this community is not "out there" but is embedded in the institutions and relations that shape our lives. Religious dogma, legal institutions, cultural practices, and traditions that promote or prohibit homosexual are influenced by and give any influence to the legal structure, social hierarchy, political system, and even interpersonal relationship. Shari'a the colonial law on sodomy and the American legal system establish and are shaped by the racial, religious, cultural and political relation of LGBT across social boundaries. As a result, how LGBT is viewed and interpreted in an Islamic context becomes multifaceted and multidimensional.

In relation to the experience of LGBT Muslims, it can be put forward the result of an interview carried out by the researcher as follows:

"We teach our own gay friends how to be Muslim people who are responsible for themselves and their family and also for the state and religion. So, we desire to build them as Muslim gays, it means that they become Muslim people who keep worshiping and understanding the religious doctrine. That is what we build for our friends. So, it reduces the pressures; becoming gays is not our own choice. If we may choose, we do not choose to be gays; but it is not understood by the people, that becoming gays is not our own choice but it is destined. That's why we are trying to find out how it really will be, how far the doctrine of such religion appreciates gays; this is what we keep to fathom. We are also actually assisted by some lecturers at Sunan Kalijaga State Islamic University who also write the book, which causes a controversy in turn. It is the book concerning Islamic jurisprudence of gays, which is ongoing in composition."

Shinta Ratri's view indicates that some LGBT Muslims still believe in Islamic authenticity despite having a different sexual orientation with Muslims in general. Moreover, Shinta Ratri managed the LGBT community through education and teaching of Islamic doctrine accommodated with Islamic boarding school. This is certainly a paradox-from our viewpoint-because they blend their Islamicity and the nature of LGBT into themselves with great comfort.

The issue of LGBT behavior is complex and complicated requiring special treatment and action. In this connection, Sinyo (familiar name of Agung Sugiharto), director of Peduli Sahabat Foundation, said:

"Therefore, at the Peduli Sahabat Foundation, I finally believe in that we do not change the sexual orientation, but adopt the advertisement jingle of the Sosro Bottle Tea: " Whatever the food, the beverage remains the Sosro Bottle Tea.' So, whatever the problem, we should refer to God. We teach that at the first night someone remains comfortable despite the same sex; but through long times, there is an extraordinary development; the earlier he/she is handled, the extraordinary progress comes out, he/she is good. However, I cannot say that he/she healed or did not heal because it has to be measured. So, there must be a measurement to measure whether he/she healed or not."

As a therapist as well as a motivator, Mr. Sinyo believes that LGBT behavior is likely to heal when intensive and continuous therapy is conducted regularly, even though the term "healing"-according to him-becomes relative and needs to be measured. It is clear that there is a positive change of progress for some people infected by LGBT behavior treated by Mr. Sinyo.

\section{ACKNOWLEDGEMENTS}

This paper is based on field research in Yogyakarta and Magelang. Many people helped us conduct this research during our time in the two cities and afterward. We are grateful to Mr. Agung Sugiharto (Sinyo) and Mrs. Shinta Ratri for absorbing and meaningful interview. We are also grateful to Asep Saepuddin Jahar for his valuable commentary and feedback. We also want to thank Prof. Arskal Salim for entrusting us to conduct this research.

\section{REFERENCES}

[1] Boellstorff, Tom, The Gay Archipelago: Sexuality and Nation in Indonesia, Princeton and Oxford: Princeton University Press, 2005.

[2] Blackwood, E., "Regulation of Sexuality in Indonesian Discourse: Normative Gender, Criminal Law and Shifting Strategies of Control", in Journal of Culture, Health and Sexuality, Vol. 9, Issue 3, 2007

[3] Corrêa, Sonia, Rosalind Petchesky and Richard Parker, Sexuality, Health and Human Rights, New York: Routledge, 2008.

[4] Cviklová, Lucie, "Advancement of Human Rights Standards for LGBT People Through the Perspective of International Human Rights Law", in Journal of Comparative Research in Anthropology and Sociology, Volume 3, Number 2, 2012.

[5] Čvorović, Jelena, "Islamic Homosexuality", (Unpublished paper).

[6] Francesca, Ersilia, "AIDS in Contemporary Islamic Ethical Literature", 21 MED. \& L. 381, 384-385, 2002 in Shafiqa Ahmadi, "Islam and Homosexuality: Religious Dogma, Colonial Rule, and the Quest for Belonging“, in Journal of Civil Rights and Economic Development, Issue 3, Vol. 26, 2012.

[7] Fried, Susan T., "Sexuality and Human Rights", in Journal of Health and Human Rights.

[8] Gerhards, Jurgen, "Non-Discrimination towards Homosexuality: The European Union's Policy and Citizens' Attitudes towards Homosexuality in 27 European Countries“, in Journal of International Sociology, January 2010, Vol. 25 (1).

[9] Hendricks, Muhsin, "Islamic Texts: A Source for Acceptance of Queer Individuals into Mainstream Muslim Society“, The Equal Rights Review, Vol. Five (2010).

[10] Ichwan, Moch. Nur, "Sharia and Queer Activism: Politics of Sexuality in Aceh", 2013.

[11] Kugle, Scott Siraj al Haqq, "Sexuality, Diversity, and Ethics in the Agenda of Progressive Muslims", in Omid Safi, (ed.), Progressive Muslims: On Justice, Gender, and Pluralism, England: One World Publications, 2003. 
[12] Md Yusof, Mohd Izwan bin, (et.al), "Malaysian Muslim Gay and Lesbian Community's Perspective on The Concept of Domestic Partnership and Marriage in the Qur'an. " (unpublished paper).

[13] Mulia, Musdah, "Understanding LGBT Issues in Islam: Promoting the Appreciation of Human Dignity“, 2nd CSBR Sexuality Institute, 11-18 December 2009, Istanbul, Turkey.

[14] Mulia, Musdah, Mengupas Seksualitas: Mengerti Arti, Fungsi dan Problematika Seksual Manusia Era Kita, ("Examining Sexuality: Understanding Meaning, Function and Sexual Problems of Our Times") Jakarta: Opus Press, 2015.

[15] Rehman, Javaid, Eleni Polymenopoulou, "Is Green a Part of the Rainbow? Sharia, Homosexuality and LGBT Rights in the Muslim
World“, in Fordham International Law Journal, Vol. 37, Issue 1, 2013, Article 7, Brunel Law School.

[16] Rodríguez, Diego García, Queering Indonesian Islam: Emerging Progressive Muslim Voices and LGBT Muslim Identity Negotiation, Swedia: Centre For East And South-East Asian Studies, Lund University, 2015.

[17] Safi, Omid, "What is Progressive Islam?", in International Institute for the Study of Islam in the Modern World, Vol. 13, December 2003.

[18] Williams. Walter L., "Strategies for Challenging Homophobia in Islamic Malaysia and Secular China“, in Journal of Nebula, Vol. 6, Issue 1, 2009. 